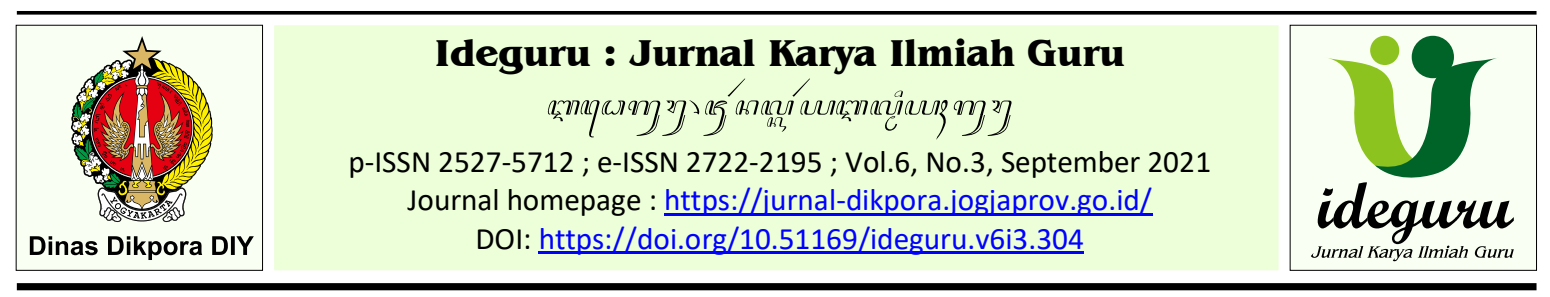

Best Practice - Naskah dikirim: 29/07/2021 - Selesai revisi: 12/08/2021 - Disetujui: 13/08/2021 - Diterbitkan: 01/09/2021

\title{
Kolaborasi Whatsapp dan Quizizz untuk Meningkatkan Hasil Belajar Siswa di Masa Pandemi Covid-19
}

\author{
Dewi Rosiani \\ SMK Negeri 1 Sewon, Bantul, Daerah Istimewa Yogyakarta, Indonesia \\ dewirosiani01@gmail.com
}

\begin{abstract}
Abstrak: Penelitian best practice ini bertujuan untuk menjelaskan pelaksanaan pembelajaran melalui kolaborasi aplikasi whatsapp dan quizizz (Whaqu) untuk meningkatkan hasil belajar siswa dan menjelaskan respon siswa terhadap pelaksanaan pembelajaran. Metode yang digunakan dalam penelitian ini adalah deskriptif kualitatif. Dari hasil studi evaluasi awal dengan membagikan angket kepada 36 siswa kelas X MIPA 1 didapatkan 94\% siswa lebih memilih WA sebagai sarana pembelajaran berbasis online dan untuk evaluasinya 58\% siswa memilih quizizz. Kolaborasi Whaqu terbukti berhasil meningkatkan hasil belajar siswa dari upaya 1 yang semula hanya 64\% siswa yang nilainya telah di atas KKM naik pada upaya 2 menjadi 83\%, upaya 3 naik menjadi 92\% upaya 4 naik menjadi 94\% dan upaya 5 naik menjadi 100\%. Selain itu, 36 siswa merespon bahwa kedua aplikasi (whatsapp dan quizizz) mudah digunakan, pelaksanaan lancar karena mudah diakses, dan efektif meningkatkan hasil belajar. Melalui pembelajaran Whaqu, karakter mereka terbangun seperti jujur, pantang menyerah, berusaha keras, mandiri, disiplin, dan menghargai waktu. Melalui kuis interaktif quizizz, siswa memiliki semangat untuk berusaha, pantang menyerah, dan mandiri untuk mendapatkan hasil yang lebih baik. Selain itu, menurut mereka, quizizz merupakan kuis interaktif yang tidak membosankan dan menarik dengan tampilan warna, animasi, musik yang membuat siswa tidak jenuh.
\end{abstract}

Kata kunci: whatsapp; quizizz; hasil belajar; pandemi covid-19

\section{Whatsapp and Quizizz Collaboration to Improve Student Learning Outcomes During the Covid-19 Pandemic}

Abstract: This best practice research aims to explain the implementation of learning through the collaboration of whatsapp and quizizz (Whaqu) applications to improve student learning outcomes and explain student responses to the implementation of learning. The method used in this research is descriptive qualitative. From the results of the initial evaluation study by distributing questionnaires to 36 students of class X MIPA 1, it was found that 94\% of students preferred WA as an online-based learning tool and for the evaluation 58\% of students chose quizizz. Whaqu's collaboration has proven to be successful in improving student learning outcomes. This statement is concluded from the data that initially only $64 \%$ of students whose scores were above the KKM in the 1 st treatment rose to $83 \%$ in the 2 nd treatment. Then in the 3rd treatment it rose to $92 \%$ and in the 4 th treatment it rose to $94 \%$. Finally on the 5 th treatment it rose to $100 \%$. In addition, 36 students responded that both applications (whatsapp and quizizz) were easy to use, smooth implementation because they were easily accessible, and effectively improved learning outcomes. Through Whaqu learning, student characters are developed such as being honest, never giving up, trying hard, being independent, disciplined, and respecting time. Through quizizz interactive quizzes, students have the spirit to try, never give up, and are independent to get better results. In addition, according to them, quizizz is an interactive quiz that is not boring and interesting with color displays, animations, music that makes students not bored.

Keywords: whatsapp; quizizz; learning outcomes; covid-19 pandemic

\section{Pendahuluan}

Global pandemi covid-19 khususnya di negara Indonesia masih menunjukan peningkatan sampai batas waktu yang belum pasti. Kejadian langka ini tampaknya merubah tatanan hidup masyarakat di pelbagai bidang, tak terkecuali bidang pendidikan. Berdasarkan SE Mendikbud No.4 tahun 2020 tentang Pelaksanaan Kebijakan dalam Masa Darurat
Penyebaran Covid-19, beberapa daerah mulai mengambil kebijakan. Kebijakan yang diambil adalah siswa belajar dari rumah (Study From Home) dan guru bekerja dari rumah (Work From Home), terhitung mulai tanggal 16-29 Maret 2020 untuk Jateng dan Jatim. Kebijakan ini lalu diikuti oleh DIY mulai tanggal 23-31 Maret 2020. Kebijakan ini lalu diperpanjang sampai batas waktu yang belum pasti. 
Sejak saat itu, pembelajaran berbasis online pun diimplementasikan para guru. Aplikasiaplikasi pembelajaran mulai dimanfaatkan guru untuk menjaga interaksi antara guru dan siswa walaupun tidak melalui tatap muka. Pemanfaatan sistem pembelajaran berbasis internet menjadi solusi cerdas guru untuk tetap melaksanakan pembelajaran jarak jauh. Aplikasi $J B$ class, Ruang Guru, Rumah Belajar, Quizizz, Kahoot, Google Classroom, Google Drive, Zoom dan sebagainya bisa dijadikan media bantu guru dalam menyampaikan materi pembelajaran dan evaluasinya selama siswa belajar di rumah.

Beragam aplikasi online yang ada pasti memiliki kelebihan dan kekurangan. Guru dapat memilah dan memilih aplikasi yang tepat dan mampu direspon positif oleh siswa. Misalkan saja zoom meeting atau webex bisa dibilang boros kuota internet selama pemakaian dan zoom meeting disinyalir kurang aman. Setyaningtyas (2020) mengatakan perangkat ini membuka celah keamanan sehingga memudahkan peretas mengakses data dan webcam para penggunanya secara diam-diam. Selain rentan malware apabila aplikasi ini dihapus, bug aplikasi masih tetap ada. Padahal dengan zoom atau webex guru dapat bertatap muka langsung dengan siswa untuk melaksanakan pembelajaran. Google classroom walaupun bagus dari segi pengarsipan dan lebih rapi karena tugas siswa dapat terkumpul sesuai kelas-kelas, tetapi terkadang siswa kesulitan untuk masuk dengan alasan sulit dijangkau dan untuk proses koreksi tugas masih dilakukan secara manual. Whatsapp walaupun dalam gawai android harus menyimpan banyak memori, tetapi lebih mudah dan cepat direspon oleh semua siswa karena siswa lebih familiar dengan aplikasi satu ini.

Walaupun begitu pembelajaran berbasis online, jelas tidak akan mampu menggantikan kehadiran seorang guru karena guru adalah roh dan spirit untuk mencapai tujuan pendidikan sesuai dengan Undang-Undang Sisdiknas No. 20 Tahun 2003. Pembelajaran berbasis online dengan berbagai aplikasi yang menarik takkan dapat menggantikan peran guru dalam mengajar karena tujuan pendidikan sesuai dengan UndangUndang Sisdiknas No. 20 Tahun 2003 tidak hanya sekedar transfer knowledge saja tetapi juga transfer value atau nilai-nilai moral. Harapannya, tidak sekedar ilmu yang didapat oleh siswa tetapi juga penanaman karakter perlu diberikan pada siswa.

Mengingat pentingnya pendidikan karakter siswa, guru harus mampu memilih media dan metode mengajar yang tepat untuk mewujudkan pembelajaran yang holistik walaupun pembelajaran dilaksanakan secara online. Dalam pembelajaran Bahasa Indonesia kelas X, untuk materi semester 2 antara lain teks biografi, teks negosiasi, teks debat disampaikan online dengan menggunakan beberapa aplikasi diantaranya google classroom, google forms, quizizz, email, dan whatsapp (WA). Diantara aplikasi tersebut yang paling sering digunakan adalah WA. Dari hasil studi evaluasi dengan membagikan angket kepada 36 siswa ternyata 34 siswa atau $94 \%$ siswa lebih memilih WA sebagai sarana yang paling baik dalam menunjang proses kelancaran pembelajaran online. Beberapa alasan yang berhasil dihimpun antara lain semua siswa dapat mengakses dan mengoperasikan WA dengan mudah, hemat kuota, jarang terkendala, lebih cepat direspon siswa, sudah terbiasa, dan mampu mengirim file, gambar, audio, video dengan sangat mudah.

Perlu diketahui bahwa siswa SMAN 1 Panggang banyak yang tinggal di daerah pelosok pegunungan sehingga tidak semua siswa memiliki keterjangkauan internet yang bagus dan tidak semua siswa memiliki gawai yang mendukung semua aplikasi dapat berjalan dengan lancar. Pada awal mula, aplikasi yang digunakan adalah google classroom, ternyata ada beberapa siswa yang tidak bisa menggunakan atau kesulitan mengakses sehingga dilakukan alternatif kedua yaitu tugas dan informasi kemudian disampaikan melalui aplikasi WA dengan alasan pesan lebih cepat direspon oleh siswa.

Pada tahap evaluasi atau latihan soal, aplikasi yang sering digunakan adalah google forms dan quizizz. Berdasarkan pembagian angket kepada 36 siswa tentang aplikasi evaluasi apa yang cocok untuk digunakan dalam pembelajaran berbasis online, 15 siswa menjawab google forms dan 21 siswa menjawab quizizz. 58 $\%$ siswa yang memilih quizizz memiliki beberapa alasan yaitu mudah dioperasikan, peluang mencontek sangat sedikit karena dibatasi waktu, menyenangkan, tidak membosankan, dan menarik dengan warna, animasi, dan musik yang memberi kesan hidup dan santai. Selain itu, dengan aplikasi quizizz siswa lebih tertantang dan memiliki semangat pantang menyerah karena dapat diulangi beberapa kali.

Berdasarkan permasalahan dan diagnosis awal terkait dengan aplikasi yang paling sesuai dan dapat diterima oleh para siswa SMAN 1 Panggang dalam menunjang pembelajaran online, maka guru akan mencoba untuk menggunakan aplikasi WA dalam penyampaian pembelajaran dan quizizz sebagai aplikasi yang digunakan dalam evaluasi pembelajaran. 
Adapun rumusan masalah dalam penelitian ini adalah (1) bagaimana pelaksanaan pembelajaran melalui kolaborasi whaqu untuk meningkatkan hasil belajar siswa pada materi teks negosiasi (2) apakah kolaborasi whaqu dapat meningkatkan hasil belajar siswa pada materi teks negosiasi (3) bagaimana respon siswa terhadap pelaksanaan pembelajaran melalui kolaborasi whaqu untuk meningkatkan hasil belajar siswa pada materi teks negosiasi.

Tujuan penelitian adalah (1) menjelaskan pelaksanaan pembelajaran melalui kolaborasi whaqu untuk meningkatkan hasil belajar siswa pada materi teks negosiasi (2) menjelaskan kolaborasi whaqu untuk meningkatkan hasil belajar siswa pada materi teks negosiasi (3) menjelaskan respon siswa terhadap pelaksanaan pembelajaran melalui kolaborasi whaqu untuk meningkatkan hasil belajar siswa pada materi teks negosiasi.

Manfaat penelitian ini adalah (1) bagi siswa dapat meningkatkan hasil belajar dan karakter siswa walaupun kegiatan pembelajaran dilaksanakan secara online (2) bagi guru dapat meningkatkan keterampilan dan kreativitas guru dalam menyusun konsep serta kemampuan untuk mengaplikasikan metode pembelajaran online yang variatif disesuaikan dengan konteks dan tujuan belajar (3) bagi peneliti dapat mengetahui lebih banyak lagi aplikasi pembelajaran berbasis online yang dapat digunakan untuk pembelajaran.

\section{Tinjauan Pustaka Pembelajaran Online}

Pembelajaran online terpaksa harus dilaksanakan mengingat belum meredanya pandemi covid-19. Pembelajaran jarak jauh dengan berbantuan media seperti laptop atau gawai yang terhubung dengan internet menjadi pengganti pembelajaran konvensional atau tatap muka seperti yang sudah biasa dilakukan selama ini.

Pembelajaran online atau online learning merupakan salah satu solusi dalam pembelajaran jarak jauh yang perlu dilakukan di era pandemi covid-19 ini dengan alasan untuk tetap memenuhi hak peserta didik dalam memperoleh layanan pendidikan, melindungi masyarakat dari dampak buruk covid-19, mencegah penularan virus corona, dan mendukung psikososial pendidik, peserta didik, orangtua/wali (kemdikbud, 2020).

Pembelajaran online merupakan suatu sistem yang diharapkan mampu memfasilitasi siswa belajar lebih luas, lebih banyak, dan bervariasi. Melalui fasilitas yang tersedia dalam pembelajaran online, siswa akan dapat belajar di mana saja, kapan saja, dan dengan siapa saja atau dari sumber belajar manapun.

Online learning menurut William (dalam Riyana, 2020) adalah a large collection of computers in networks that are tied together so that many users can share their vast resources. Dalam pengertian ini, pembelajaran online meliputi aspek perangkat keras seperti komputer, laptop, bahkan sekarang gawai (infrastruktur) yang saling berhubungan satu sama lain dan memiliki kemampuan untuk mengirimkan data, baik berupa teks, gambar, suara, bahkan video.

Pembelajaran online yang pada awal pandemi merupakan sesuatu yang masih sangat baru menuntut para pendidik untuk dapat mengoperasikan dan memilah serta memilih yang sesuai dengan kebutuhan peserta didik. Namun, pembelajaran online mempunyai kelebihan sekaligus kelemahan. Di satu sisi, para siswa dituntut untuk lebih mandiri, tapi disisi lain para siswa merasa jenuh. Hasil UNICEF Indonesia 5-8 Juni 2020 pada 4.000 lebih anak Indonesia mengungkap mayoritas $69 \%$ anak bosan belajar di rumah. Melalui portal U-report diketahui 38\% merasa tidak mendapat bimbingan guru, dan $35 \%$ tidak dapat menjangkau internet sehingga terkendala dalam belajar (UNICEF, 2020). Selain itu, hasil Penelitian yang dilakukan oleh Dwi C dkk (2020: 1) menyebutkan bahwa pembelajaran online kurang efektif karena faktor kurangnya sarana dan prasarana serta ketidaksiapan edukasi teknologi.

Berbagai upaya yang dilakukan untuk mengatasi permasalahan terkait dengan pembelajaran online yang dilakukan selama belajar di rumah adalah adanya dukungan orangtua untuk memberikan rasa aman, tenang, keyakinan diri, dan memberi harapan. Guru juga perlu memberi bantuan dan dukungan dengan mengedepankan pembelajaran yang lebih bermakna dengan menggunakan aplikasi yang cocok dan sesuai dengan kebutuhan siswa. Sekolah dan Pemerintah Daerah juga terus memantau dan mengapresiasi pembelajaran online yang dilakukan oleh para guru sehingga tercipta kerjasama yang sinergis untuk mewujudkan pembelajaran online di tengah pandemi covid-19.

\section{Peningkatan Hasil Belajar}

Dalam suatu proses pembelajaran perlu dilakukan evaluasi untuk mengetahui tingkat keberhasilan siswa dalam melaksanakan proses pembelajaran. Apakah telah terjadi perubahan dari yang sebelumnya belum tahu menjadi tahu atau yang sebelumnya baik menjadi lebih baik. 
Perubahan yang terjadi dalam diri siswa dapat disebut sebagai hasil belajar. Hasil belajar merupakan proses perubahan tingkah laku pada diri seseorang yang dapat diamati dan diukur dalam bentuk pengetahuan, keterampilan, dan sikap. Perubahan artinya adanya peningkatan dan pengembangan tingkah laku yang lebih baik dari sebelumnya (Hamalik, 2007: 30).

Hasil belajar dapat berupa nilai belajar siswa yang didapat melalui kegiatan pengukuran dan penilaian. Tujuan utama dari hasil belajar adalah untuk mengetahui tingkat keberhasilan siswa setelah mengikuti proses pembelajaran yang biasanya ditandai dengan skala nilai berupa huruf, angka, atau simbol (Mudjiono, 2009: 200).

Dari pengertian tersebut maka dapat disimpulkan bahwa hasil belajar adalah proses perubahan tingkah laku yang dapat diamati dan diukur dalam ranah pengetahuan, keterampilan, dan sikap yang didapat dari kegiatan pengukuran dan penilaian. Hasil belajar yang diharapkan dalam penelitian ini adalah nilai yang diperoleh siswa dan perubahan sikap setelah melakukan kegiatan pembelajaran berkenaan dengan materi teks negosiasi.

\section{Aplikasi Whatsapp}

WhatsApp (WA) adalah aplikasi perpesanan gratis yang tersedia untuk android dan gawai lainnya. WA menggunakan koneksi internet untuk berkomunikasi dengan orang lain tanpa terbatas ruang dan waktu. Menurut Dahlal (2020) whatsapp is the message-sharing social media app, is commonly used by students to collaborate on class assignments.

Aplikasi WA saat ini semakin canggih, selain dapat melakukan pesan tulis, suara, video, video call, saat ini untuk video call dapat dilakukan secara group atau lebih dari satu orang. Melalui aplikasi WA ini siswa lebih mudah untuk mengoperasikan. Mereka bisa mengirim pesan secara tertulis, pesan suara, gambar, video dan banyak lagi hanya dengan satu aplikasi ini. WA lebih banyak digunakan dalam pembelajaran berbasis online alasannya semua siswa telah mengenal dan mengoperasikan WA dengan sangat baik.

Dalam pembelajaran online aplikasi ini sangat membantu kelancaran komunikasi antara guru dan siswa. Sebuah penelitian "Whatsapp, Teacher?" mengungkapkan bahwa whatsapp di dalam kelas telah menjadi komunikasi utama. Siswa menyebutkan banyak keuntungan dari komunikasi WA seperti akses yang mudah, kemampuan membuat komunitas belajar, kemampuan menjaga privasi, dan format komunikasi. Baik guru maupun siswa memandang WA sebagai sarana komunikasi yang disukai karena pelanggaran privasi yang minimal (Rosenberg, 2018).

\section{Aplikasi Quizizz}

Quizizz adalah aplikasi berbasis internet yang biasanya digunakan dalam kegiatan asesmen atau penilaian pembelajaran. Quizizz dapat digunakan untuk penilaian diagnostik, formatif, atau sumatif. Quizizz menyediakan berbagai permainan kuis yang interaktif dan menyenangkan. Penggunaannya sangat mudah dan pengguna dapat memilih beberapa opsi pertanyaan dan jawaban yang diinginkan. Selain itu, dalam quizizz dapat ditambahkan gambar sebagai latar belakang pertanyaan dan dapat mengatur tampilan gambar sesuai keinginan. Terdapat warna-warna yang cerah dan musik sekaligus animasi-animasi untuk selingan ketika menjawab kuis. Apabila, kuis yang dibuat sudah selesai dibuat, maka dapat dibagikan kepada siswa dengan menggunakan kode yang sudah disetel.

Quizizz selain memberikan pertanyaan dan jawaban secara interaktif juga memberikan data statistik tentang kinerja siswa. Pengguna atau guru dapat melacak siapa saja siswa yang sudah menjawab, berapa skor jawaban dan akurasi jawaban berdasarkan ketepatan waktu. Quizizz juga dapat dijadikan pekerjaan rumah dengan batas waktu yang sudah diatur sebelumnya (Bahar, 2017). Dengan aplikasi evaluasi quizizz, siswa dapat belajar di mana saja, kapan saja tanpa ada paksaan. Selama pembelajaran online siswa dapat mengerjakan di rumah dengan gawainya masing-masing, dibuat untuk PR atau pekerjaan rumah dengan membatasi waktu pengerjaan tersebut hingga 2 minggu. Dengan quizizz, siswa bisa bermain kapan saja dan dari mana saja. Selama pembelajaran online siswa dapat mengerjakannya di rumah.

Untuk memulai permainan quizizz ada beberapa langkah yaitu (1) pengguna masuk ke laman www.quizizz.com lalu sign up melalui akun google, (2) memilih opsi sebagai guru, siswa, orang tua atau lainnya, (3) pengguna dapat melengkapi data dan isian info, (4) pengguna dapat memilih buat ketika akan membuat kuis, atau pengguna dapat langsung memilih kuis-kuis yang sudah ada sesuai dengan kebutuhan, (5) ketika pengguna memilih untuk membuat kuis baru, maka selanjutnya adalah menuliskan nama kuis dan mata pelajaran, (6) selanjutnya pengguna dapat memulai membuat kuis dengan membuat pertanyaan dengan berbagai ragam seperti pilihan ganda, esai, 
survei, dan sebagainya, (7) pengguna juga dapat memilih teleport untuk menggunakan pertanyaan-pertanyaan yang telah ada, (8) pengguna dapat memilih "question preview" untuk menampilkan soal yang telah dibuat dan klik finished atau terbitkan bila sudah selesai, (9) tahap akhir, pilih grade atau tingkatan, subjects atau mata pelajaran lalu simpan, (10) pengguna kemudian dapat memilih apakah kuis digunakan secara langsung atau untuk pekerjaan rumah, (11) setting kuis lalu pilih tugaskan sehingga akan muncul kode dan link untuk bergabung, (12) pengguna meminta siswa bergabung dengan membuka join.quizizz.com, dan menuliskan kode yang sudah diberikan

Berikut adalah tampilan kode yang dapat dibagikan ke siswa (gambar 1).

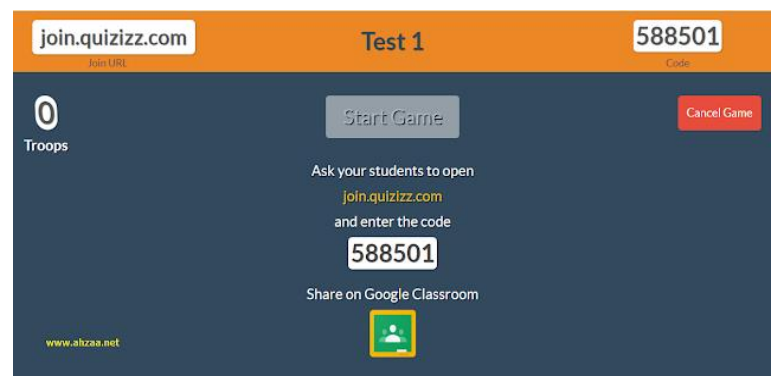

Gambar 1. Tampilan quizizz yang berisi kode yang dibagikan ke siswa

Berdasarkan hasil penelitian yang dilakukan oleh Unik Hanifah dkk (2020) aplikasi quizizz sangat efektif digunakan dalam proses pembelajaran. Hasil yang dicapai dalam aplikasi quizizz sebagai media pembelajaran, yakni: (1) Perhatian siswa dalam menggunakan handphone dalam proses pembelajaran, (2) Pemahaman siswa memahami soal secara mandiri, (3) Keaktifan, baik bertanya mengenai materi maupun mengevaluasi dan mencatat materi, (4) Ketelitian siswa terhadap soal dan manajemen waktu, (5) Ketenangan dalam mengerjakan soal atau kuis.

Evaluasi pembelajaran dengan menggunakan media quizziz sebenarnya dapat dimanfaatkan untuk semua materi dalam pembelajaran mata pelajaran apapun. Pada kesempatan ini, media evaluasi quizizz diujicobakan dalam pembelajaran Bahasa Indonesia. Pada materi-materi sebelumnya seperti teks Laporan Hasil Observasi, quizizz telah digunakan dan berhasil mendapat respon yang positif dari siswa. Pada kesempatan ini, quizizz akan diujicobakan dalam pembelajaran Bahasa Indonesia materi teks negosiasi. Sebelum dilakukan evaluasi dengan menggunakan quizizz, siswa sudah mengerjakan evaluasi dengan soalsoal yang ditulis di microsoft word yaitu soal pilihan ganda berjumlah 10 dan ternyata hasil belajar siswa masih rendah yaitu hanya 15 siswa yang tuntas sehingga 21 siswa atau 58\% siswa belum tuntas. Dengan menggunakan media evaluasi quizizz harapannya nilai siswa materi negosiasi dapat meningkat.

\section{Teks Negosiasi}

Menurut Suherli (2017: 151) negosiasi pada dasarnya ialah proses tawar menawar dengan jalan berunding guna mencapai kesepakatan bersama antara satu pihak dengan pihak yang lain. Tujuan negosiasi adalah mengatasi atau menyesuaikan perbedaan untuk mencapai kesepakatan bersama. Unsur-unsur pembangun negosiasi adalah adanya partisipan atau pihak yang terlibat dalam negosiasi, adanya perbedaan kepentingan, adanya pengajuan-penawan, adanya kesepakatan sebagai hasil negosiasi.

Faktor yang menentukan keberhasilan negosiasi yaitu kesediaan beberapa pihak untuk saling berkompromi, tidak ada pihak yang dirugikan, kesepakatan yang dicapai praktis atau dapat dilaksanakan, alasan yang disertakan mampu mempengaruhi pihak lain. Pola penyajian teks negosiasi adalah teks dalam bentuk dialog dan narasi yang disertai dialog. Struktur teks negosiasi terdiri dari orientasi, pengajuan, penawaran, pengajuan, penawaran, persetujuan, dan penutup.

\section{Pembahasan}

Pelaksanaan kegiatan pembelajaran berbasis online dengan materi teks negosiasi dapat berjalan dengan lancar dengan menggunakan kolaborasi whaqu (whatsapp dan quizizz). Pada pertemuan pertama dengan tujuan pembelajaran siswa dapat merangkum materi teks negosiasi dengan menggunakan peta konsep (mind mapping) berjalan dengan lancar dengan menggunakan aplikasi WA.

Indikator keberhasilan pada proses pembelajaran materi teks negosiasi adalah $75 \%$ siswa mendapat nilai KKM. Nilai KKM adalah 75. Tujuan pembelajarannya adalah siswa dapat merangkum materi teks negosiasi dari video yang telah dilampirkan secara lengkap, kreatif, dan menarik. Rangkuman materi tersebut dibuat dalam peta konsep sehingga mudah dipahami oleh siswa.

Tugas siswa terkumpul pada hari itu juga. Dari 36 siswa hanya 1 siswa yang belum mengumpulkan (inisial EK) dengan alasan tidak dapat dihubungi baik melalui WA maupun media sosial lain sehingga untuk siswa tersebut tugas akan disusulkan di kemudian hari. Untuk hasil belajar pada proses pembelajaran pertemuan 
pertama semua siswa mendapatkan nilai di atas KKM yaitu terendah 80 dan tertinggi adalah 88 . Berikut adalah salah satu contoh hasil mind mapping siswa (Gambar 2).

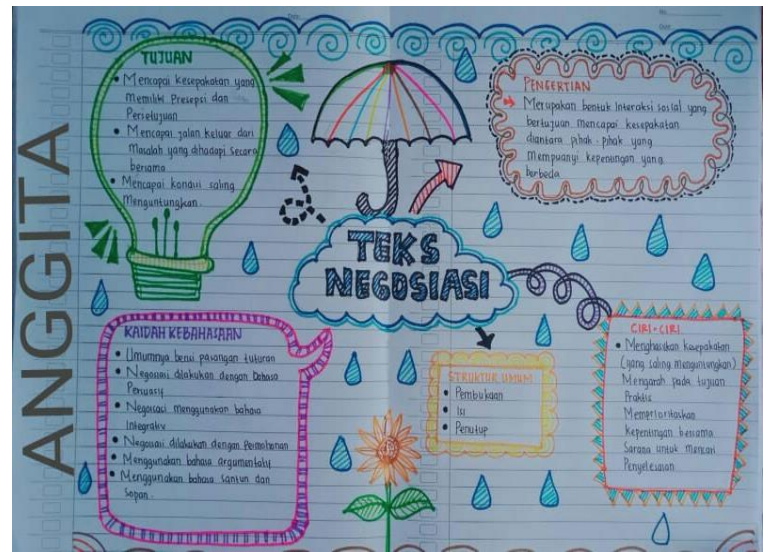

Gambar 2. Mind Map materi teks negosiasi

WA sebagai aplikasi yang sudah populer di kalangan siswa menjadi aplikasi yang paling mudah diterapkan dan jarang terkendala dalam pembelajaran online. Beberapa alasan siswa lebih memilih WA sebagai sarana komunikasi dalam pembelajaran online adalah mudah dalam mengakses dan mengoperasikan, hemat kuota, jarang terkendala, lebih cepat direspon siswa, sudah terbiasa, dan mampu mengirim file, gambar, audio, video dengan sangat mudah. Hal ini senada dengan hasil penelitian Dahlal (2020) dalam Using the WhatsApp Social Media Application for Active Learning yang menunjukkan bahwa diskusi melalui WA sangat efektif, meningkatkan motivasi, dan mahasiswa dapat berpartisipasi secara aktif dalam topik kuliah.

Penelitian ini sejalan dengan hasil studi evaluasi awal bahwa 94\% siswa lebih memilih WA sebagai sarana yang paling baik dalam menunjang proses kelancaran pembelajaran online. Beberapa alasan yang berhasil dihimpun antara lain semua siswa dapat mengakses dan mengoperasikan WA dengan mudah, hemat kuota, jarang terkendala, lebih cepat direspon siswa, sudah terbiasa, dan mampu mengirim file, gambar, audio, video dengan sangat mudah. Oleh karena itu, pada kesempatan kali ini aplikasi WA digunakan untuk mempermudah kelancaran pembelajaran online. Berikut adalah komunikasi dan pengumpulan tugas siswa melalui WA (Gambar 3).
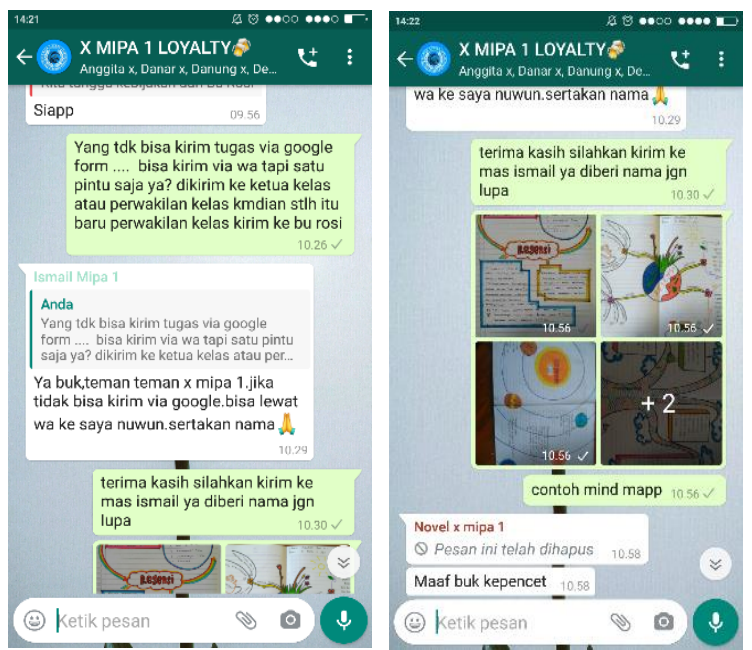

Gambar 3. Penggunaan WA untuk komunikasi dan pengumpulan tugas

Pada pertemuan kedua yaitu dengan tujuan pembelajaran latihan soal terkait dengan materi teks negosiasi dilakukan dengan menggunakan aplikasi quizizz. Sebelumnya telah dilakukan evaluasi dengan menggunakan tes tulis yaitu pilihan ganda. Dari 36 siswa hanya $42 \%$ siswa yang tuntas dan $58 \%$ masih belum tuntas. Oleh karena itu, dilakukan kembali evaluasi penilaian dengan menggunakan media yang berbeda yaitu menggunakan aplikasi quizizz. Soal pilihan ganda dengan jumlah soal 10.

Dari hasil evaluasi dengan menggunakan quizizz dari 36 siswa pada upaya pertama hanya 23 siswa yang telah tuntas KKM dengan nilai 80 s.d. 100, kemudian pada upaya dua meningkat menjadi 30 siswa, masih ada 6 siswa yang belum mencapai nilai KKM sehingga harus remidi atau mengulang lagi. Kemudian pada upaya ketiga meningkat 33 siswa yang nilainya di atas KKM. Pada upaya keempat 34 siswa dan pada upaya kelima 36 siswa telah mencapai nilai di atas KKM. Alasan ada beberapa siswa yang belum tuntas pada upaya 4 dan 5 adalah karena siswa tersebut memang kurang motivasi dalam belajar sehingga harus selalu diberi motivasi untuk tetap semangat dan berusaha keras untuk hasil nilai yang lebih baik. Untuk lebih jelasnya dapat dilihat pada tabel 1 sebagai berikut.

Tabel 1. Peningkatan Hasil belajar Siswa

\begin{tabular}{llcccl}
\hline \multicolumn{1}{c}{ Nilai } & Upaya 1 & Upaya 2 & Upaya 3 & Upaya 4 & Upaya 5 \\
\hline 70 ke atas & $23(64 \%)$ & $30(83 \%)$ & $33(92 \%)$ & $34(94 \%)$ & $36(100 \%)$ \\
70 ke bawah & $13(36 \%)$ & $6(17 \%)$ & $3(8 \%)$ & $2(6 \%)$ & 0 \\
\hline Jumlah Siswa 36 & $36(100 \%)$ & $36(100 \%)$ & $36(100 \%)$ & $36(100 \%)$ & $36(100 \%)$ \\
\hline
\end{tabular}


Peningkatan hasil belajar siswa setelah menggunakan aplikasi quizizz dapat dilihat pada grafik berikut:

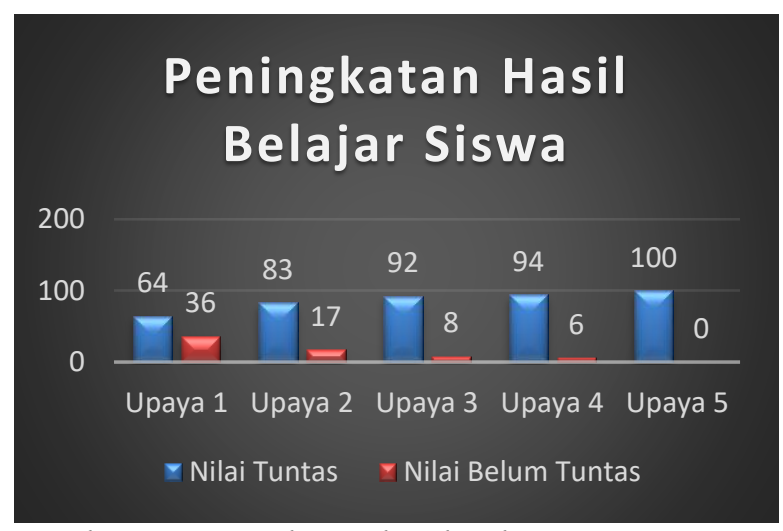

Gambar 4. Peningkatan hasil Belajar Siswa

Dari pembelajaran tersebut dapat disimpulkan bahwa kolaborasi whaqu dapat meningkatkan hasil belajar siswa karena ketika siswa belum mencapai KKM maka mereka akan belajar kembali dan mencoba mengerjakan kembali, begitu berulang-ulang sampai nilainya mencapai di atas KKM. Selain itu. Dengan permainan melalui kuis interaktif ini dominan siswa merespon dan sangat antusias untuk mengerjakan soal melalui aplikasi quizizz, bahkan ada siswa yang mengharapkan agar aplikasi quizizz dapat digunakan sebagai aplikasi Penilaian Akhir Tahun (PAT) online.

Dari pembagian angket terhadap 36 siswa untuk mengetahui respon siswa terhadap pembelajaran berbasis online dengan kolaborasi whaqu adalah sebagai berikut (1) kedua aplikasi mudah digunakan (2) pelaksanaan lancar karena mudah diakses (3) efektif meningkatkan hasil belajar dan karakter siswa (4) menarik karena terhibur dengan musik, animasi, dan tulisannya (5) media yang cocok untuk mengatasi kejenuhan. Selain itu, dari 36 siswa atau 100\% siswa menyampaikan bahwa aplikasi quizizz dapat membangun karakter siswa seperti jujur, pantang menyerah, berusaha keras, mandiri, disiplin, dan menghargai waktu.

\section{Simpulan dan Saran}

Dari uraian tentang laporan best practice di atas dapat ditarik simpulan sebagai berikut (1) peningkatan hasil belajar dan karakter siswa menjadi bagian yang harus diupayakan dalam sebuah pembelajaran. Pada kesempatan siswa belajar di rumah karena Pandemi covid-19, guru harus mampu memilah dan memilih aplikasi pembelajaran online yang tepat dan mudah direspon siswa serta menyenangkan sehingga siswa tidak jenuh belajar di rumah (2) kolaborasi whaqu terbukti berhasil meningkatkan hasil belajar siswa dari upaya 1 yang semula hanya $64 \%$ siswa yang nilainya telah di atas KKM naik pada upaya 2 menjadi $83 \%$, upaya 3 naik menjadi $92 \%$ upaya 4 naik menjadi $94 \%$ dan upaya 5 naik menjadi $100 \%$ (3) kolaborasi whaqu juga dapat membangun karakter siswa seperti jujur, pantang menyerah, berusaha keras, mandiri, disiplin, dan menghargai waktu. Bagi siswa yang nilainya masih di bawah KKM melalui kuis interaktif quizizz akan selalu berupaya untuk berusaha, pantang menyerah, dan mandiri untuk mendapatkan hasil yang lebih baik. Quizizz juga terbukti sebagai kuis interaktif yang tidak membosankan dan menarik dengan tampilan warna, animasi, musik yang membuat siswa tidak jenuh.

Saran untuk para guru Bahasa Indonesia dan guru mapel lainnya dapat menggunakan aplikasi pembelajaran berbasis online seperti WA, Google Forms, Quizizz, dan aplikasi lain disesuaikan dengan situasi dan kondisi yang ada untuk meningkatkan hasil belajar dan sekaligus karakter siswa. Selain itu, perlu ada kerjasama dan kekompakan dari siswa, guru, orangtua, kepala sekolah, dan pengawas untuk memastikan kelancaran proses pembelajaran berbasis online.

\section{Daftar Pustaka}

Bahar, Ayunara. (2017). Membuat Kuis Interaktif Kelas dengan Quizizz. Dipetik tanggal $28 \mathrm{Mei}$ 2020

dari http://www.ahzaa.net/2017/08/membuatkuis-interaktif-kelas-dengan.html

Dahlal, Sohail. (2020). Using the WhatsApp Social Media Application for Active Learning. Journal of Educational Technology Systems, 49(2).

https://journals.sagepub.com/doi/abs/10.1 177/0047239520928307

Dwi C, Brilliannur, dkk. (2020). Analisis Keefektifan Pembelajaran Online di Masa Pandemi Covid-19. Jurnal Pendidikan Guru Sekolah Dasar. Universitas Trunojoyo Madura.

Google, Play. (2020). Whatsapp Messenger. Dipetik tanggal 2 Juni 2020 pada https://play.google.com/store/apps/details ?id=com. whatsapp\&hl=in

Hamalik, Oemar. (2007). Proses Belajar Mengajar. Jakarta: Bumi Putera

Kemdikbud, (2020). SE Sekjen Kemendikbud No. 15 Tahun 2020 tentang Pedoman Penyelenggaraan Belajar Dari Rumah Dalam Masa Darurat Penyebaran Corona Virus Disease (Covid-19) http://bersamahadapikorona.kemdikbud.go id/ 
Kemdikbud, (2020). SE Mendikbud No.4 tahun 2020 tentang Pelaksanaan Kebijakan dalam Masa Darurat Penyebaran Covid-19 https://pusdiklat.kemdikbud.go.id/suratedaran-mendikbud-no-4-tahun-2020tentang-pelaksanaan-kebijakan-pendidikandalam-masa-darurat-penyebaran-coronavirus-disease-covid-1-9/

Mudjiono, (2009). Belajar dan Pembelajaran. Jakarta: Rhineka Cipta.

Riyana, Cepi (2020). Konsep pembelajaran Online. Pustaka.ut.ac.id

Salsabila, Unik Hanifah, dkk. (2020). Pemanfaatan Aplikasi Quizizz Sebagai Media Pembelajaran Ditengah Pandemi Pada Siswa SMA. Jurnal Ilmiah Ilmu Terapan Universitas Jamb, 4(2).

Rosenberg, Hananel \& Christa S. (2018). "WhatsApp, Teacher?" - Student Perspectives on Teacher-Student WhatsApp Interactions in Secondary Schools. Journal of
Information Technology Education: Research, 17, 205-226.

Setyaningsih, Ulfa. (2020). Berhati-hatilah Pengguna Aplikasi Zoom. Dipetik tanggal 28 Mei dari https://mojok.co/terminal/berhatilah-hatipengguna-aplikasi-zoom/

Suherli, dkk. (2017). Bahasa Indonesia SMA/MA/SMK/MAK Kelas X. Jakarta: Kemdikbud.

UNICEF. (2020). Pendidikan Anak Indonesia: Belajar Jarak Jauh dan Tinjauan Kesiapan Menuju Belajar Tatap Muka. Dipetik tanggal 28 Mei 2020 dari https://www.unicef.org/indonesia/id/medi a/8251/file

Wikimedia. (2020). Whatsapp. Dipetik tanggal 2 Juni 2020 pada https://id.wikipedia.org/wiki/WhatsApp 